\title{
Article \\ Exploring the Assembly of Resorc[4]arenes for the Construction of Supramolecular Nano-Aggregates
}

\author{
Fabio Buonsenso ${ }^{1}\left(\mathbb{D}\right.$, Francesca Ghirga ${ }^{1}\left(\mathbb{D}\right.$, Isabella Romeo ${ }^{1,2}$, Gabriella Siani $^{3}$, Serena Pilato ${ }^{3} \mathbb{D}$, \\ Deborah Quaglio ${ }^{1, *}$, Marco Pierini ${ }^{1, *}$ (D) Bruno Botta ${ }^{1}(\mathbb{C})$ and Andrea Calcaterra ${ }^{1}$ (I) \\ 1 Department of Chemistry and Technology of Drugs, "Department of Excellence 2018-2022", Sapienza \\ University of Rome, P. le Aldo Moro 5, 00185 Rome, Italy; fabio.buonsenso@uniroma1.it (F.B.); \\ francesca.ghirga@uniroma1.it (F.G.); isabella.romeo@uniroma1.it (I.R.); bruno.botta@uniroma1.it (B.B.); \\ andrea.calcaterra@uniroma1.it (A.C.) \\ 2 Center for Life Nano and Neuroscience, Italian Institute of Technology, Viale Regina Elena 291, \\ 00161 Rome, Italy \\ 3 Department of Pharmacy, University of Chieti "G. D'Annunzio", Via dei Vestini 31, 66013 Chieti, Italy; \\ gabriella.siani@unich.it (G.S.); serena.pilato@unich.it (S.P.) \\ * Correspondence: deborah.quaglio@uniroma1.it (D.Q.); marco.pierini@uniroma1.it (M.P.)
}

\section{check for} updates

Citation: Buonsenso, F.; Ghirga, F.; Romeo, I.; Siani, G.; Pilato, S.; Quaglio, D.; Pierini, M.; Botta, B.; Calcaterra, A. Exploring the Assembly of Resorc[4]arenes for the Construction of Supramolecular Nano-Aggregates. Int. J. Mol. Sci. 2021, 22, 11785. https://doi.org/ 10.3390/ijms222111785

Academic Editors: Ian A. Nicholls and Vladimir N. Uversky

Received: 16 September 2021

Accepted: 26 October 2021

Published: 29 October 2021

Publisher's Note: MDPI stays neutral with regard to jurisdictional claims in published maps and institutional affiliations.

Copyright: (c) 2021 by the authors. Licensee MDPI, Basel, Switzerland. This article is an open access article distributed under the terms and conditions of the Creative Commons Attribution (CC BY) license (https:/ / creativecommons.org/licenses/by/ $4.0 /)$.

\begin{abstract}
Many biologically active compounds feature low solubility in aqueous media and, thus, poor bioavailability. The formation of the host-guest complex by using calixarene-based macrocycles (i.e., resorcinol-derived cyclic oligomers) with a good solubility profile can improve solubilization of hydrophobic drugs. Herein, we explore the ability of resorc[4]arenes to self-assemble in polar solutions, to form supramolecular aggregates, and to promote water-solubility of an isoflavone endowed with anti-cancer activity, namely Glabrescione B (GlaB). Accordingly, we synthesized several architectures featuring a different pattern of substitution on the upper rim including functional groups able to undergo acid dissociation (i.e., carboxyl and hydroxyl groups). The aggregation phenomenon of the amphiphilic resorc[4]arenes has been investigated in a THF/water solution by UVvisible spectroscopy, at different $\mathrm{pH}$ values. Based on their ionization properties, we demonstrated that the supramolecular assembly of resorc[4]arene-based systems can be modulated at given $\mathrm{pH}$ values, and thus promoting the solubility of GlaB.
\end{abstract}

Keywords: resorc[4]arenes; supramolecular assembly; solubilizing agents; Glabrescione B; UV-vis spectroscopy

\section{Introduction}

A wide range of biologically active compounds suffers from poor aqueous solubility impairing their bioavailability and, as a result, their preclinical and clinical development. The self-assembly process of well-defined structures from various chemical building blocks have found exponential growth in the development of drug delivery and bio-nanotechnology systems [1]. In particular, these assemblies give the possibility to encapsulate pharmaceutically active compounds in their core (or at their surface) and to cargo them to the therapeutic targets [2]. Self-assembly can include different levels of complexity: it can be as simple as the dimerization of two small building blocks driven by hydrogen bonding or more complicated as a cell membrane [1], a remarkable supramolecular architecture created by a bilayer of phospholipids embedded with functional proteins. In addition to a vast series of natural amphiphilic structures, several "engineered" synthetic architectures have been designed as solubilizing agents, using a macrocyclic core such as cyclodextrins and crown-ethers [2-13]. Among the large pool of macrocycles available, calixarene-based macrocycles are one of the most ubiquitous host molecules in supramolecular chemistry. These macrocycles are cyclic oligomers characterized by a unique three-dimensional surface, featuring several phenolic units bound with methylene 
bridges, which can form large hydrophobic cavities. The high versatility of their chemical structure, which can be variously functionalized at both the upper and lower rims, allows the combination of hydrophilic and hydrophobic groups favoring the amphiphilic behavior of macrocycles and the formation of self-associates with a varying morphology [14]. Supramolecular complexation techniques using calixarene-based macrocycles as hosts may improve not only the solubility but also the stability of the guest molecules (including drugs), several examples of calixarene-guest aggregates have been reported [15-17]. In order to overcome the low aqueous solubility of these macrocycles, the upper or lower rim can be easily functionalized with water soluble groups containing positive or negative charges [18-24]. Among them, sulfonated calixarenes have dominated drug solubility studies [16]. Within the calixarene family, resorcinol-derived cyclic oligomers, namely resorc[4]arenes, endowed with cavities of molecular dimension, behave as an efficient artificial receptor $[14,25,26]$. The synthetic modularity and different complexation properties of the resorcarene-based macrocycles make them a promising building block for the design and synthesis of more sophisticated supramolecular architectures [27-31]. Efficient solubilizing agents were designed and developed by using several resorc[4]arenes [15,32,33]. Recently, Morozonova et al. reported that aggregates of amphiphilic calix-resorcinarenes, featuring amidoamino and dimethylamino peripheral groups on the upper rim and different aliphatic groups (pentyl, octyl, and undecyl) on the lower rim, behave as effective solubilizing agents of hydrophobic drugs containing a carboxyl group (e.g., naproxen, ibuprofen, and ursodeoxycholic acid) [34]. The driving force of the association process is the ionization of organic acids and the peripheral nitrogen atoms of the macrocycles with the subsequent inclusion of hydrophobic acids into the macrocycle self-associates. Intriguingly, the solubilization of carboxylic acids in more than an equimolar ratio leads to the co-assembly of the macrocycle polydisperse associates into supramolecular monodisperse nanoparticles with the diameter of about $100 \mathrm{~nm}$ [34]. However, to date, a limited use of resorcarene derivatives as an amphiphilic host to complex poorly water-soluble drugs has been made with the purpose of enhancing their water-solubility and bioavailability. In a previous study, we demonstrated that physical descriptors, namely the aggregation polarity index (API), the cavitation Gibbs free-energy change ( $\Delta \Delta \mathrm{Gcav})$, and the decrease of the molecular surface (A) after the exposure of solute to the solvent upon aggregation $(\% \Delta \mathrm{A})$, were able to monitor the propensity of a double-spanned resorc[4]arene derivative (BSK), featuring a basket-like structure, to self-assembly in tetrahydrofuran (THF)/water solutions [29]. Based on these findings, with the aim to investigate the self-aggregation propensity of resorc[4]arene macrocycles, several architectures featuring a different pattern of substitution on the upper rim, including functional groups able to undergo acid dissociation, were synthesized (Figure 1). The self-assembly capability in polar solutions of amphiphilic resorc[4]arenes R1, R2, and R3, containing on the upper rim ester, carboxyl, and hydroxyl groups, respectively, were explored by UV-visible spectroscopy. Based on the ionization properties of $\mathbf{R} \mathbf{2}$ and $\mathbf{R} \mathbf{3}$, we demonstrated that, by varying the $\mathrm{pH}$ values, the supramolecular assembly of resorc[4]arene-based systems can be driven in polar solutions paving the way for the design and construction of new drug formulations.<smiles>[R]c1cc([R])c(C([R])c2cc(C([R])c3cc(C([R])c4cc([R])c(C([R])[R])cc4[R])c([R])cc3[R])c([R])cc2[R])cc1[R]</smiles>

R1 R=n- $\mathrm{C}_{11} \mathrm{H}_{23} ; \mathrm{R}{ }_{1}=\mathrm{OCH}_{3} ; \mathrm{R}_{2}=\mathrm{OCH}_{2} \mathrm{CO}_{2} \mathrm{CH}_{3}$

R2 $\mathrm{R}=\mathrm{n}-\mathrm{C}_{11} \mathrm{H}_{23} ; \mathrm{R}_{1}=\mathrm{OCH}_{3} ; \mathrm{R}_{2}=\mathrm{OCH}_{2} \mathrm{COOH}$

R3 R= n- $\mathrm{C}_{11} \mathrm{H}_{23} ; \mathrm{R}_{1}=\mathrm{R}_{2}=\mathrm{OH}$

Figure 1. Chemical structure of amphiphilic resorc[4]arenes R1, R2, and R3. 


\section{Results and Discussion}

The construction of supramolecular assemblies by using amphiphilic molecular species is one of the most promising employable approaches to deliver hydrophobic pharmaceutically active compounds in physiological fluids. In principle, a suitable modulation of the self-assembly process can be effectively achieved in polar solvents by performing a proper chemical modification of the peripheral portion of the selected host, in terms of number and/or type of the hydrophilic groups. As such, the exploitation of supramolecular assembly of resorc[4]arenes represents a key approach to encapsulate hydrophobic bioactive compounds into their wide lipophilic and relatively flexible cavityshaped architecture. In a previous study, we synthesized a cavity-shaped resorc[4]arene resembling a basket (BSK, Figure 2) via a ring closing metathesis reaction, and we investigated its self-aggregation propensity by UV-visible spectroscopy (Figure 2) [29]. To this aim, we developed a set of physical descriptors that, together, allowed us to calculate the hydrophilic-hydrophobic balance of the macrocycle. In this context, the Hildebrand polarity index $\left(\delta_{\mathbf{H}}\right)$ was employed as an indicator of the macrocycle affinity to the corresponding solvent system; a specific parameter, namely API, which corresponds to the $\delta_{\mathbf{H}}$ of the solvent mixture at which a self-aggregation process has reached the $50 \%$, was used to reflect in a quantitative fashion the hydrophilic-hydrophobic nature of the molecule and, thus, its amphiphilicity [29].

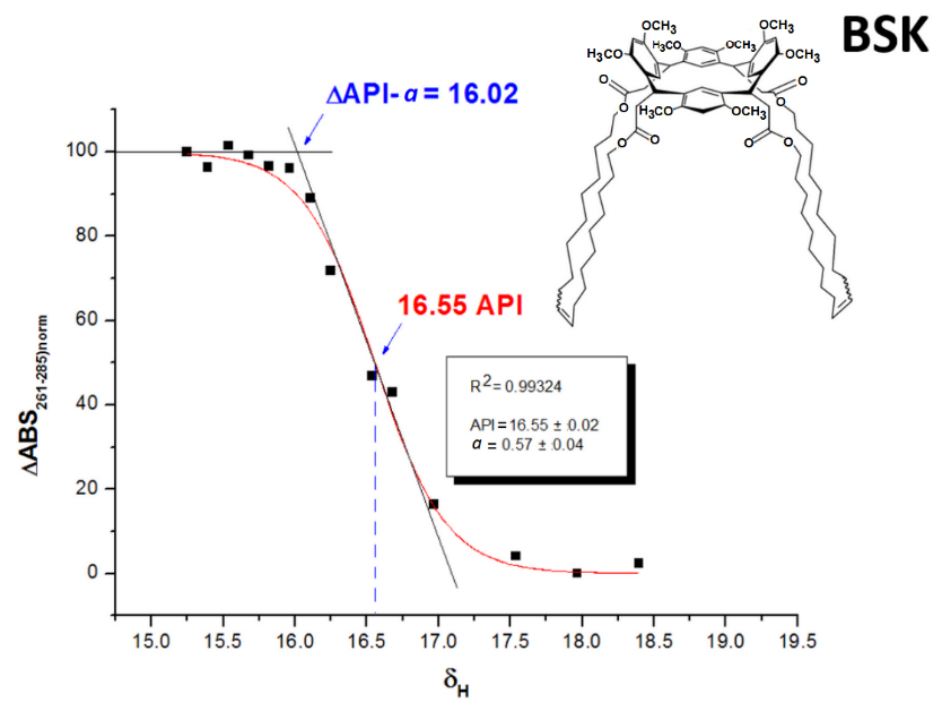

Figure 2. Sigmoidal aggregation profile of BSK as obtained in THF/water solvent system. The API parameter estimated for BSK from linear fitting of sigmoidal plot of $\mathbf{\Delta} \mathbf{A B S}_{\mathbf{3 5 0} \mathbf{4 0 0}} \mathrm{vs}$. $\boldsymbol{\delta}_{\mathbf{H}}$ is reported.

The BSK resorcarene demonstrated a clear propensity to undergo self-aggregation in THF/water solvent systems. The aggregation phenomenon begins when the solvent composition shows a $\delta_{\mathbf{H}}$ value of 16.0 , i.e., THF/water $=52: 48(v / v)$, and stops when $\delta_{\mathbf{H}}$ is about 17.1, i.e., THF/water $=44: 56(v / v)$ [29]. Specifically, the API index of BSK selfaggregation corresponded to a $\delta_{\mathbf{H}}=16.55\left(\mathrm{kcal} \times \mathrm{dm}^{3}\right)^{1 / 2}$ in the THF/water composition of 48/52 $(v / v)$ [29]. The moderate API value found for BSK suggests that the hydrophobic nature of the macrocycle largely overcomes the hydrophilic one. In general, the linear relation between $\delta_{\mathbf{H}}$ and the water percentage of the THF/water mixture can be expressed by the following regression line achieved for the plot $\delta_{H}$ vs. $\mathbf{H}_{2} \mathbf{O} \%\left(\delta_{\mathbf{H}}\right.$ values have been obtained by the linear combination shown here: $\mathrm{H}_{2} \mathrm{O} \% \times \delta_{\mathrm{H}-\mathrm{of}-\mathrm{H}_{2} \mathrm{O}}+\mathrm{THF} \% \times$ $\boldsymbol{\delta}_{\mathbf{H - o f}-\mathrm{THF}}$, with the Hildebrand polarities $\boldsymbol{\delta}_{\mathbf{H}-\mathbf{o f}-\mathrm{H}_{2} \mathbf{O}}$ and $\boldsymbol{\delta}_{\mathbf{H}-\mathrm{of} \text {-THF }}$ amounting to 23.4 and 9.1, respectively) [35]:

$$
\delta_{\mathbf{H}}=0.1435 \times \mathbf{H}_{\mathbf{2}} \mathbf{O} \%+9.0929
$$

Based on this evidence, by increasing the hydrophilic character of the resorc[4]arene macrocycles through their upper rim chemical modification, the API parameter, as well as 
the range when the self-aggregation process occurs, should undergo a progressive shift towards greater values of $\boldsymbol{\delta}_{\mathbf{H}}$, corresponding to solutions largely rich in water which are able to give rise to a more effective solvation. Accordingly, we decided to synthesize three resorc[4]arene derivatives (R1, R2, and R3, Figure 3), featuring the same four alkyl chains in the lower rim, but different upper rim functionalization, and to investigate their self-assembly tendency by UV-visible spectroscopy. With respect to R1 which contains four methyl ester groups, the $\mathbf{R} \mathbf{2}$ and $\mathbf{R} 3$ macrocycles own ionizable functions in their hydrophilic portion (i.e., carboxyl or phenolic groups). As predicted by theoretical $\mathrm{pK}_{\mathrm{a}}$ values calculated through the Marvin program [36] (Figure 3), the degree of deprotonation of such groups can be finely modulated by the employment of the THF/water mixtures at a fixed $\mathrm{pH}$ value $\mathrm{X}$ of the aqueous component $(\mathrm{pH})$. Accordingly, to perform the self-assembly investigation of the ionizable resorc[4]arenes, the $\mathrm{pH}_{\mathrm{X}}$ was set by using a suitable buffer solution, i.e., THF/(buffer- $\mathrm{pH}_{\mathrm{X}}$ ) mixtures.

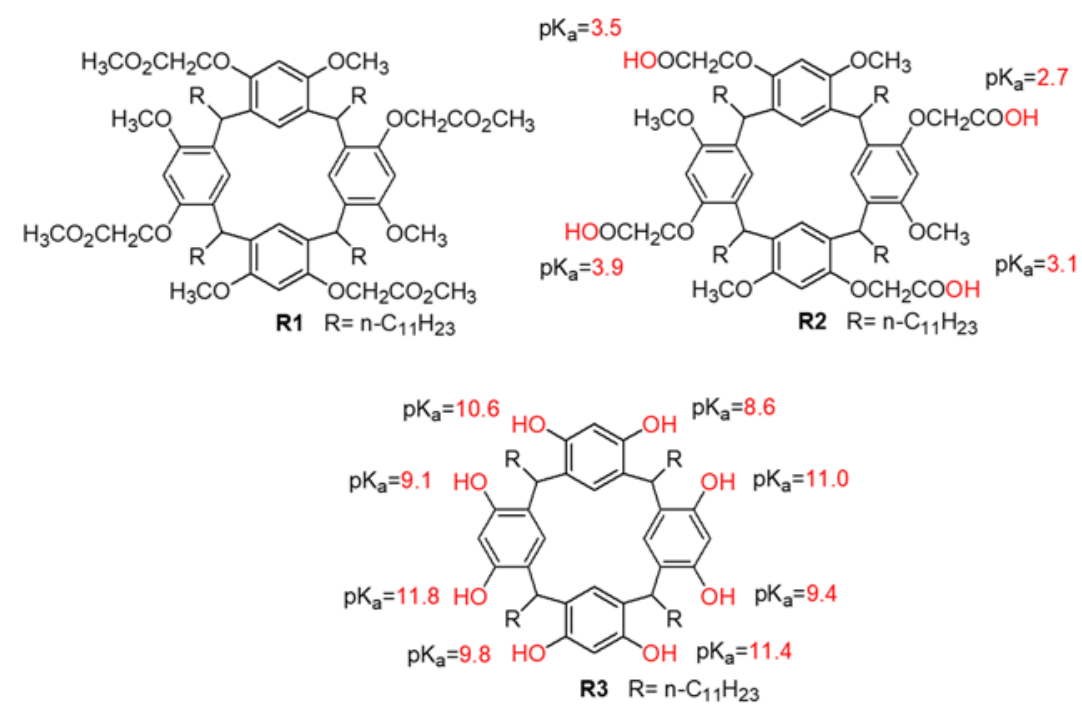

Figure 3. Structure of amphiphilic resorc[4]arenes $\mathbf{R} 1, \mathbf{R} 2$, and $\mathbf{R} 3$, and $\mathrm{pK}_{\mathrm{a}}$ of acid groups calculated by Marvin program.

\subsection{Synthesis of Amphiphilic Resorc[4]arene Macrocycles}

With the aim of constructing systems for $\mathrm{pH}$-induced self-assembly of amphiphilic resorc[4]arenes, we introduced in the resorc[4]arene macrocycle scaffold four long nonpolar hydrocarbon chains in the lower rim and polar groups in the upper rim. Resorcarene R3 was prepared according to the literature [37,38]. Tetramethoxyresorcarenes (3) and R1 were obtained by slight modifications of the synthetic procedures reported by Li et al [39]. The synthetic route to resorc[4]arenes $\mathbf{R} \mathbf{1}$ and $\mathbf{R} \mathbf{2}$ is reported in Scheme 1. Compound 3 was obtained by a tetramerization reaction of 3-methoxyresorcinol (1) with dodecanal (2). Successively, the phenol groups of resorcarene 3 were functionalized with methyl bromoacetate in the presence of potassium carbonate as a base, to obtain resorcarene R1, which bears methyl ester moieties in the upper rim. Finally, the ester functionalities of R1 were hydrolyzed with $2 \mathrm{M}$ of potassium hydroxide and then the solution was acidified with hydrochloric acid to obtain the resorc[4]arene tetraacid R2. All these ${ }^{1} \mathrm{H}$ NMR and ${ }^{13} \mathrm{C}$ NMR spectroscopical data were identical to the literature for compounds $\mathbf{3}$ and R1 [39]. Compound R2, which was unknown, has been fully characterized by NMR and HRMS. 


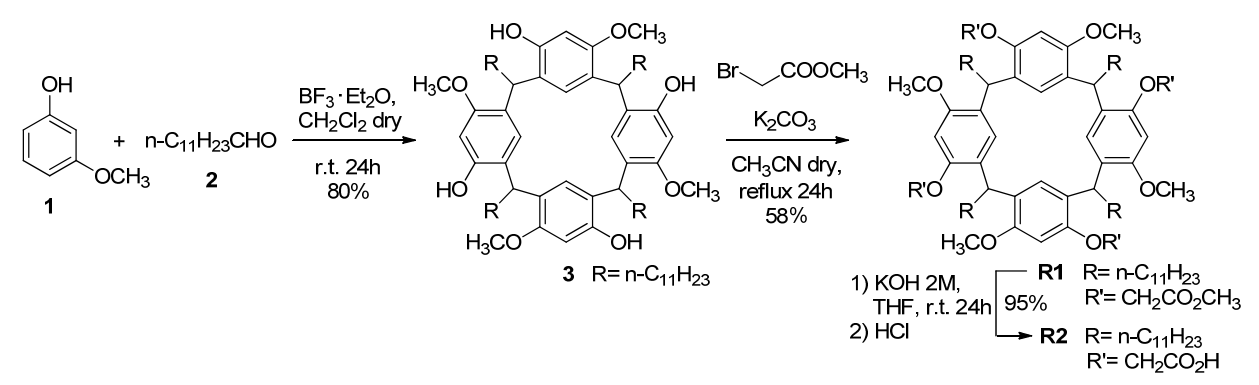

Scheme 1. Synthesis of amphiphilic resorc[4]arenes $\mathbf{R} \mathbf{1}$ and $\mathbf{R} \mathbf{2}$.

For all the resorc[4]arenes, the ${ }^{1} \mathrm{H}$ and ${ }^{13} \mathrm{C}$ NMR spectral data are featured by the presence of single signals for equivalent internal and external aromatic protons and carbons, suggesting a cone conformation with C4v symmetry in solution (Figure 4). Accordingly, in addition to having a greater hydrophilic character, resorc[4]arenes R1-R3 are less preorganized and are more flexible systems with respect to BSK, in which a flattened cone conformation occurs for the presence of the two cyclic alkenes (Figure 4).

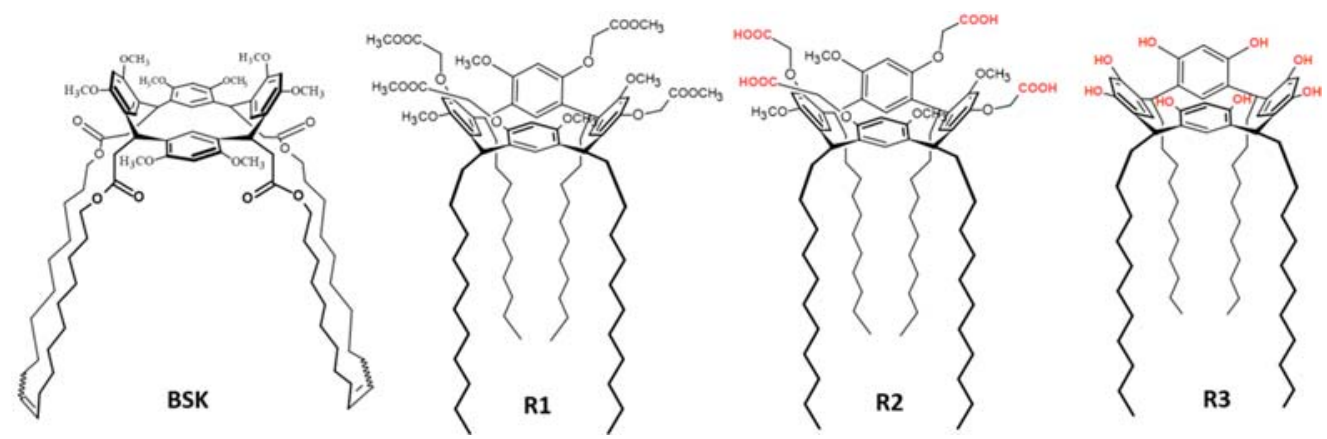

Figure 4. 3D chemical structure of BSK and of amphiphilic resorc[4]arenes R1, R2, and R3.

\subsection{The Self-Association of Resorc[4]arene $\mathbf{R} \mathbf{1}$ in THF/Water Solution}

The resorc[4]arene R1, which features similar structure to $\mathbf{R} \mathbf{2}$ but endowed with a non-ionizable upper rim (- $\mathrm{COOCH}_{3}$ in place of $\left.-\mathrm{COOH}\right)$, was used as a reference system to compare its self-assembly behavior with that of the ionizable resorc[4]arenes. Accordingly, we investigated the aggregation propensity of resorc[4]arene $\mathbf{R} \mathbf{1}$ in THF/water mixtures by varying progressively the non-polar and polar solvent components in the $\delta_{\mathbf{H}}$ range from $9.1(100 \%$ of THF) to $21.3(\mathrm{THF} /$ water $=15: 85, v / v)$. For this purpose, the concentration of $\mathbf{R} 1$ was kept at a constant value of $3.2 \times 10^{-5} \mathrm{M}$. The self-association process was monitored by registering the changes in the UV-absorbance difference at the wavelengths of 350 and $400 \mathrm{~nm}\left(\mathrm{ABBS}_{350-400}\right)$ as a function of the $\boldsymbol{\delta}_{\mathbf{H}}$ value of the corresponding solvent system. The scatter plot of $\Delta \mathbf{A B S}_{350-400} \mathrm{vs} \delta_{\mathrm{H}}$ was further fitted by using the following equation $[29,40]$ :

$$
\Delta \mathbf{A B S}_{350-400}=\mathrm{b} /\left(1+10^{(-(\boldsymbol{\delta} \mathbf{H}-\mathbf{A P I}) / \mathrm{a})}\right.
$$

with $\mathrm{b}$ and a parameters representing the maximum value assumed by $\mathbf{\Delta} \mathbf{A B S}_{350-400}$ and the slope of the sigmoidal curve, respectively. As depicted in Figure 5, the self-aggregation of $\mathbf{R} 1$ is featured by an API value of 17.3 which corresponds to a water amount of $57.3 \%$ (with $\mathrm{a}=0.42$ ). This means that the resorc[4]arene assembly starts approximately when the THF/water composition yields $\delta_{\mathbf{H}}=16.9\left(54.6 \%\right.$ of water) and stops when $\delta_{\mathbf{H}}=17.7$ (60.1\% of water composition). At the end of the $\mathbf{R} \mathbf{1}$ self-association process, a suspension with visible turbidity is formed (Figure 5). Although R1 does not possess ionizable groups, to further characterize the structure in terms of lipophilic/hydrophilic balance of the macrocycle and to allow the comparison of its lipophilicity with that of resorc[4]arenes $\mathbf{R} 2$ and $\mathbf{R} 3$, the distribution coefficient in the logarithmic form, $\log (\mathrm{D})$, was calculated through the Marvin program [36]. In general, $\log (\mathrm{D})$ is a widely used descriptor measuring 
the lipophilicity of ionizable biologically active compounds, where the partition in two immiscible solvents (octan-1-ol/water) is a function of the $\mathrm{pH}$. Lower values of $\log (\mathrm{D})$ correspond to structures endowed with higher aqueous solubility. Specifically, the $\log (\mathrm{D})$ value of the resorc[4]arene $\mathbf{R} \mathbf{1}$ was established to be 21.8 .

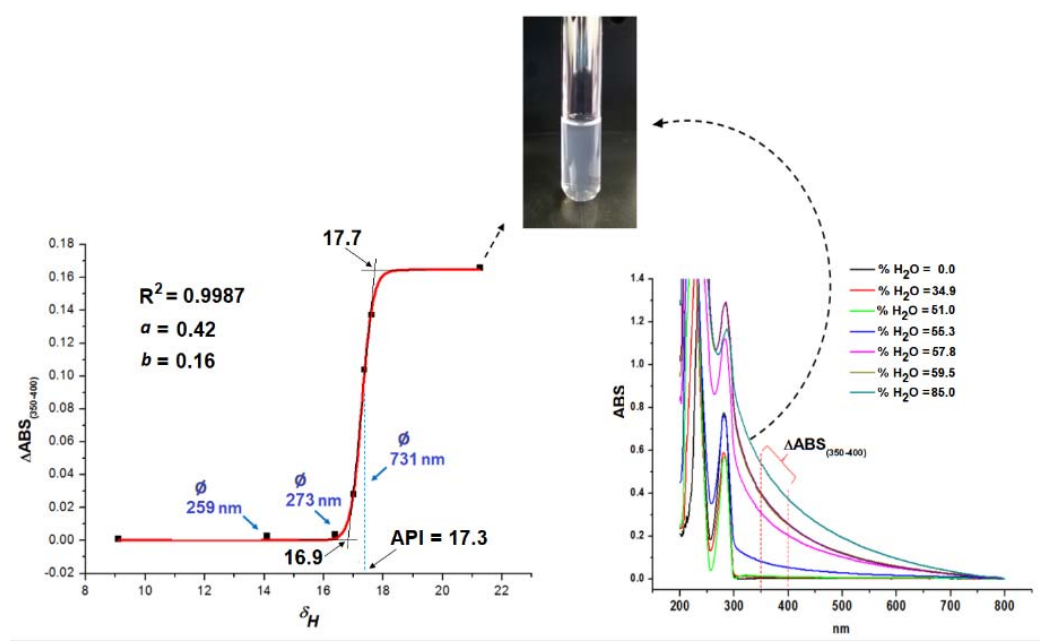

Figure 5. On the left, the sigmoidal aggregation profile of resorc[4] arene $\mathbf{R} \mathbf{1}$ as obtained in THF/water solvent system. Regression analysis to fit the experimental data was performed according to Equation (2). On the right, the UV-visible spectra of resorc[4]arene R1 $\left(3.2 \times 10^{-5} \mathrm{M}\right)$ in different $\mathrm{THF} /$ water solvent systems.

\subsection{The Self-Association of Ionizable Resorc[4]arenes $\mathbf{R} 2$ and $\mathbf{R} 3$ in $T H F /\left(B u f f e r-p H_{X}\right)$ Solution}

Due to the presence of four carboxyl groups in the upper rim, the $\mathbf{R} \mathbf{2}$ degree of lipophilicity can be modulated in the $\log (\mathrm{D})$ range from 21.6 to -5.2 by inducing the formation of the ionized forms at different $\mathrm{pH}$ values (in the range of 2.0-11.4). Accordingly, to investigate the self-assembly behavior of resorc[4] arene R2, the UV-visible spectroscopic analysis was performed by using the THF/(buffer- $\left.\mathrm{pH}_{\mathrm{X}}\right)$ mixtures. To establish the final $\mathrm{pH}$ value (i.e., apparent $\mathrm{pH}$ ) in the resulting $\mathrm{THF} /($ buffer $\mathrm{pH}$ ) solution, the THF effect was experimentally measured up to its total amount of $50 \%$ in the mixture (see Figure S1). Specifically, as highlighted in Figure S1, the $\mathrm{pH}$ variation in the aqueous solution was overall rather modest reaching the maximum deviation at $\mathrm{pH} 8.4(\Delta \mathrm{pH}=0.54$ units $)$. To explore the influence of the $\mathbf{R} \mathbf{2}$ deprotonation degree on the $\boldsymbol{\delta}_{\mathbf{H}}$ ranges at which the selfassembly process begins and finishes, three different $\mathrm{pH}$ values (i.e., 1.9, 6.2, and 8.7) of the aqueous component employed in the THF/(buffer- $\left.\mathrm{pH}_{\mathrm{X}}\right)$ mixtures were chosen. The ratio between the non-polar and the polar components of the solvent system was progressively varied in the $\delta_{\mathbf{H}}$ range from $9.1(100 \% \mathrm{THF})$ to $21.3(15 \% \mathrm{THF} / 85 \%$ water), when using buffer- $\mathrm{pH}_{1.9}$ and buffer- $\mathrm{pH}_{6.2}$ solutions, and in the $\delta_{\mathbf{H}}$ range from 9.1 (100\% THF) to 22.7 ( $5 \% \mathrm{THF} / 95 \%$ water), when using a buffer- $\mathrm{pH}_{8.7}$ solution. In all cases, the $\mathbf{R} \mathbf{2}$ concentration was maintained at a fixed value of $3.0 \times 10^{-5} \mathrm{M}$. The self-aggregation plots of $\mathbf{R} \mathbf{2}$, registered as a function of the THF/(buffer $\mathrm{pH}_{\mathrm{X}}$ ) mixtures at the three above-mentioned $\mathrm{pH}$ values, are reported in Figure 6. By using a buffer-pH1.9 solution, the ionization of the resorc[4]arene $\mathbf{R} 2$ is substantially suppressed and the $\log (\mathrm{D})$ value accounts for 21.6. The total charge on the upper rim of $\mathbf{R} \mathbf{2}$ was estimated to be -0.2 , corresponding to the following distribution of each unionized and ionized species in water: $85 \%$ of the uncharged form; $14 \%$ of the mono-anionic form; and $1 \%$ of the di-anionic form. In the THF/(buffer- $\left.\mathrm{pH}_{1.9}\right)$ mixture, the aggregation process of $\mathbf{R} 2$ starts at $\boldsymbol{\delta}_{\mathbf{H}}=17.3$ (57.3\% of water) and stops at $\boldsymbol{\delta}_{\mathbf{H}}=20.9(82.5 \%$ of water). By comparing the self-assembly of $\mathbf{R} \mathbf{2}$ with that of $\mathbf{R} \mathbf{1}$, the more hydrophilic resorc[4]arene $\mathbf{R} 2(\log (\mathrm{D})=21.6 \mathrm{vs} \log (\mathrm{D})=21.8)$ begins the aggregation at a little bit greater $\delta_{\mathbf{H}}$ value $\left(\delta_{\mathbf{H}}=17.3\right.$ vs. $\delta_{\mathbf{H}}=16.9$, corresponding to a difference of $+2 \%$ in water), and completes the process to a higher $\boldsymbol{\delta}_{\mathbf{H}}$ value $\left(\boldsymbol{\delta}_{\mathbf{H}}=20.9\right.$ vs. $\boldsymbol{\delta}_{\mathbf{H}}=17.7$, corresponding to a difference of $+23 \%$ in water). 

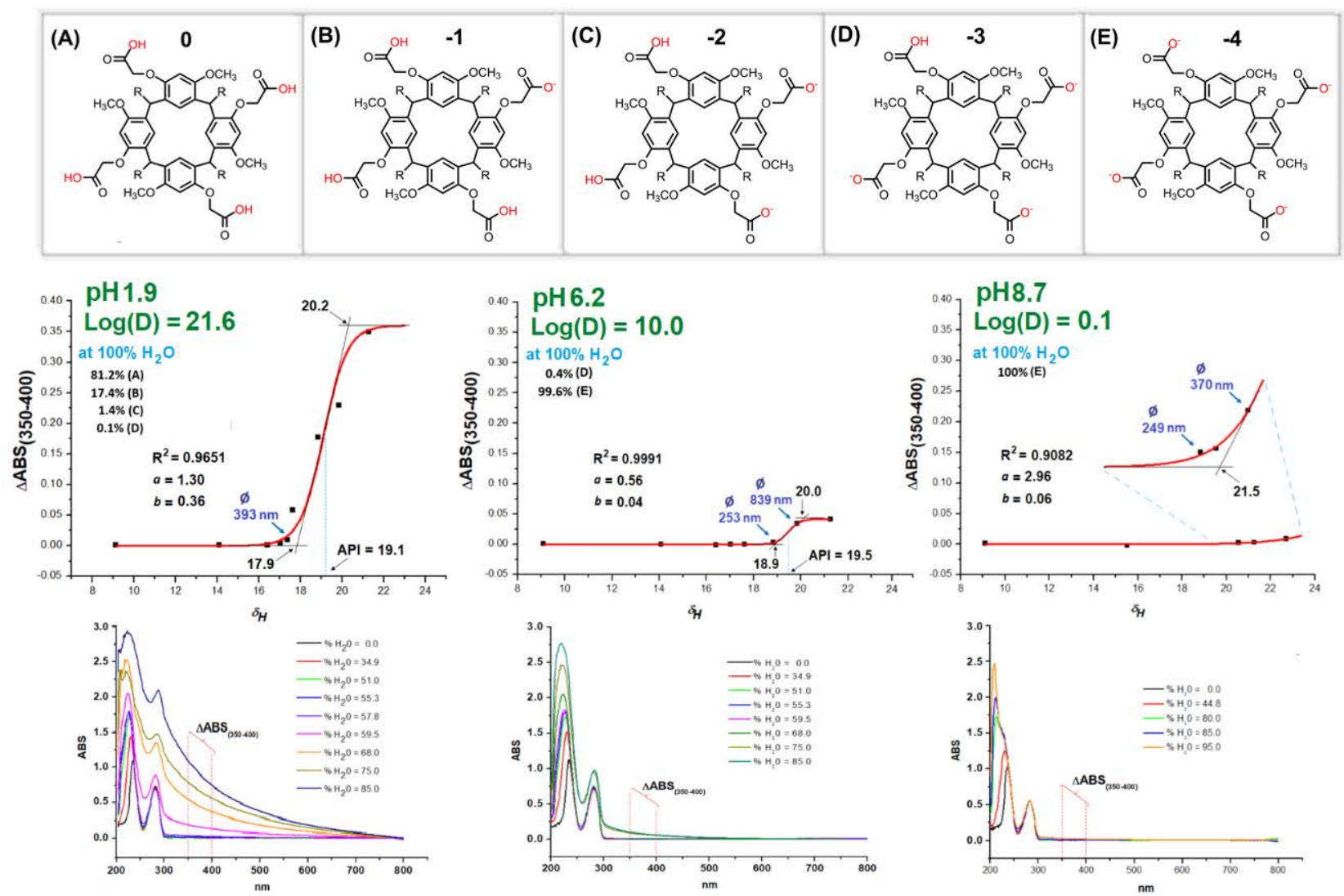

\begin{tabular}{|c|c|c|c|c|c|c|c|c|}
\hline$\delta_{H}$ & 10 & 12 & 14 & 16 & 18 & 20 & 22 & 23 \\
\hline & & & & & & & & \\
\hline$\% \mathrm{H}_{2} \mathrm{O}$ & 6.3 & 20.3 & 34.3 & 48.3 & 62.2 & 76.2 & 90.2 & 97.2 \\
\hline$\%$ THF & 93.7 & 79.7 & 65.7 & 51.7 & 37.8 & 23.8 & 9.8 & 2.8 \\
\hline
\end{tabular}

Figure 6. The sigmoidal aggregation profile and the corresponding UV-visible spectra of resorc[4]arene $\mathbf{R} 2$ as obtained in $\mathrm{THF}$ / water solvent systems at fixed $\mathrm{pH}$ values of the aqueous component. Regression analysis to fit the experimental data was performed according to Equation (2). Subfigures (A-E) represent the deprotonation states of $\mathbf{R} \mathbf{2}$ at the analyzed $\mathrm{pH}$ values of 1.9, 6.2 and 8.7 (the relevant percentages are shown next to the respective aggregation plots).

When the aggregation process of $\mathbf{R} \mathbf{2}$ was performed at the higher $\mathrm{pH}$ values (i.e., 6.2 and 8.7), marked changes in the $\boldsymbol{\delta}_{\mathbf{H}}$ values, as well as in the API and a parameters, were found. In particular, by employing a buffer $\mathrm{pH} 6.2$ solution, the self-assembly of $\mathbf{R} 2$, featuring an estimated $\log (\mathrm{D})$ of 10.0 , is comprised in the $\boldsymbol{\delta}_{\mathbf{H}}$ range from 18.9 to 20.0 , with API and a parameters of 19.5 and 0.56 , respectively. At the end of this aggregation process, the solution appears slightly turbid, with the self-assembled molecules of $\mathbf{R} 2$ showing a surfactant action evidenced by the formation of a small foam layer (Figure 7). When the self-aggregation process of $\mathbf{R} \mathbf{2}$ was carried out by using the THF/(buffer-pH $\mathrm{H}_{8.7}$ ) solvent mixture, more drastic changes on the API and a parameters, as well as on the $\delta_{\mathbf{H}}$ value at which the assembly starts, were observed. In a buffer- $\mathrm{pH}_{8.7}$ solution, the resorc[4]arene $\mathbf{R} 2$ is characterized by a $\log (\mathrm{D})$ of 0.1 , and it is completely deprotonated. As such, the process is triggered when $\delta_{\mathbf{H}}$ reaches the value of 20.5 (i.e., $86 \%$ of water), with the API and a parameters assessed equal to 22.5 (i.e., $94 \%$ of water composition) and 2.17, respectively. In these conditions, unlike in buffer- $\mathrm{pH}_{1.9}$ and buffer- $\mathrm{pH}_{6.2}$ systems, at the end of the self-assembly process a clear solution appears, featured by a very low $\Delta \mathbf{A B S}_{350-400}$ value of 0.01 (about ten times lesser than that registered for the aggregated form of $\mathbf{R} 2$ at $\mathrm{pH}=6.2$ ). The self-assembled molecules of $\mathbf{R} 2$ show a strong surfactant action, as evidenced by the formation of a thick layer of foam (Figure 7). These results suggest that, in such an experimental condition, the resorc[4]arene $\mathbf{R} \mathbf{2}$ might act as an effective molecular shuttle of 
hydrophobic structures. Interestingly, the $\log (\mathrm{D})$ value of 0.1 assessed for $\mathbf{R} 2$ at $\mathrm{pH}=8.7$ corresponds to the one owned by the stearic acid at $\mathrm{pH}=11.5$ and by the palmitic acid at $\mathrm{pH}=10.5$ (values calculated by Marvin [36]). The sodium salts of these fatty acids, which are the common components of natural soaps, are typically characterized in water by $\mathrm{pH}$ values close to 11. Thus, resorc[4]arene $\mathbf{R 2}$ at a $\mathrm{pH}$ of around 9 is featured by a similar lipophilic/hydrophilic balance to that of components of natural soaps.

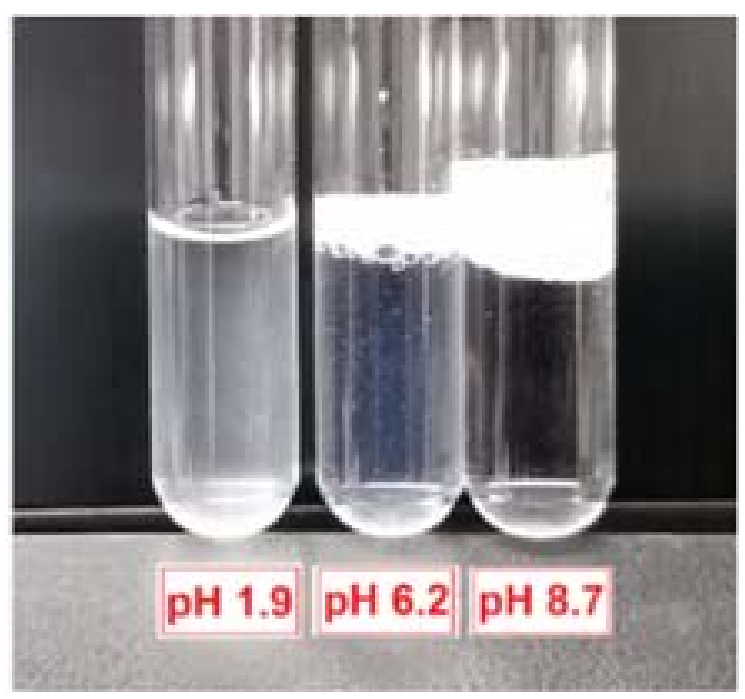

Figure 7. Turbid solution of $\mathbf{R} 2$ at $\mathrm{pH}=1.9$; clear solution of $\mathbf{R} 2$ at $\mathrm{pH}=6.2$ with some foam at liquid surface; clear transparent solution of $\mathbf{R} 2$ at $\mathrm{pH}=8.7$ with consistent formation of a foam at the liquid surface.

Further investigation was focused on the self-assembly behavior of resorc[4]arene R3, featuring eight ionizable phenolic groups on the upper rim. The aggregation process was monitored in the $\mathrm{pH}$ range from 2.4 to 11.8 by using specific THF/ (buffer- $\mathrm{pH}_{\mathrm{X}}$ ) mixtures (i.e., $X=2.4,6.2,8.5,10.0,11.8$ ), in order to allow a selective modulation of $\mathbf{R} 3$ hydrophilicity in response to an appropriate $\mathrm{pH}$ value. Accordingly, the $\log (\mathrm{D})$ values of resorc[4]arene R3 were assessed by the Marvin program [36] as a function of the selected $\mathrm{pH}$ (Figure 8) and the theoretical $\mathrm{pK}_{\mathrm{a}}$ values of the phenolic groups (Figure 3), thus reflecting the different percentages in which $\mathbf{R} 3$ is neutral or in the charged forms. The $\Delta \mathbf{A B S}_{\mathbf{3 5 0}-400}$ values plotted as a function of $\delta_{H}$ for each THF/(buffer-pHX) mixture are collected in Figure 8. From the sigmoidal plots, an initial induction of $\mathbf{R} \mathbf{3}$ self-aggregation is followed by a progressive disaggregation step, except for the THF/(buffer- $\left.\mathrm{pH}_{2.4}\right)$ mixture which preserves $\mathbf{R} 3$ in its uncharged form. To experimentally explain this trend, Dynamic Light Scattering (DLS) measurements were carried out by analyzing the diameters $\varnothing$ of the $\mathbf{R} \mathbf{3}$ aggregates in solutions prepared from a THF/(buffer- $\mathrm{pH}_{10.0}$ ) mixture in the $\boldsymbol{\delta}_{\mathbf{H}}$ range from 18.8 to 22.7 (i.e., from $68 \%$ to $95 \%$ of water composition). As outlined in Figure 9, the variation of $\varnothing$ (blue line) is perfectly related to the $\Delta \mathbf{A B S}_{350-400}$ changes at the same $\delta_{\mathbf{H}}$ range (gray line). After one hour, the DLS measurements were performed on the same solutions, showing how the $\mathbf{R} 3$ aggregates significantly increase in dimensions by a factor of 1.8 at the water composition of $75 \%$, while to a lesser extent at $68 \%$ of water (Figure 8 , orange line). Interestingly, the measured diameters of the $\mathbf{R} \mathbf{3}$ aggregates are linearly related to the $\Delta \mathrm{ABS}_{350-400}$ values at the same $\delta_{\mathbf{H}}$ index $\left(\mathrm{R}^{2}=0.9869\right)$, according to the following equation:

$$
\varnothing=18,532 \times \Delta \mathbf{A B S}_{350-400}+207.49
$$

Within the $\triangle \mathbf{A B S}_{350-400}$ range of $0.001-0.03$, this equation was employed to estimate the variation in the aggregate size of the resorc[4]arenes $\mathbf{R} \mathbf{1}, \mathbf{R} 2$, and $\mathbf{R} \mathbf{3}$ as a function of $\delta_{\mathbf{H}}$. The $\delta$ of the most significant aggregates are indicated in the sigmoidal profiles of Figures 4,5 and 7 . The propensity of the macrocycle to self-assembly with the formation of 
colloidal aggregates is clearly demonstrated from the aggregation plots of R3. At higher $\mathrm{pH}$ and $\boldsymbol{\delta}_{\mathbf{H}}$ values (water percentages greater than $85 \%$ ), their diameters are lesser than $300 \mathrm{~nm}$, giving rise to lyophilic colloids and thus to clear solutions. Nevertheless, by using a THF/(buffer- $\mathrm{pH}_{11.8}$ ) mixture at $\boldsymbol{\delta}_{\mathbf{H}}>20$ (water composition greater than $90 \%$ ), the diameter of the colloid system exceeds the above limit, reaching the value of $647 \mathrm{~nm}$ in $100 \%$ of buffer and leading to a perfectly clear solution. Similarly to resorc[4]arene $\mathbf{R} 2$ in the THF/(buffer-pH $\mathrm{H}_{8.7}$ ) solvent system at $\boldsymbol{\delta}_{\mathbf{H}}$ greater than 20.5 , the $\mathbf{R} 3$ solutions at specific $\mathrm{pH}$ and $\boldsymbol{\delta}_{\mathbf{H}}$ values might favor the solubilization of hydrophobic compounds.
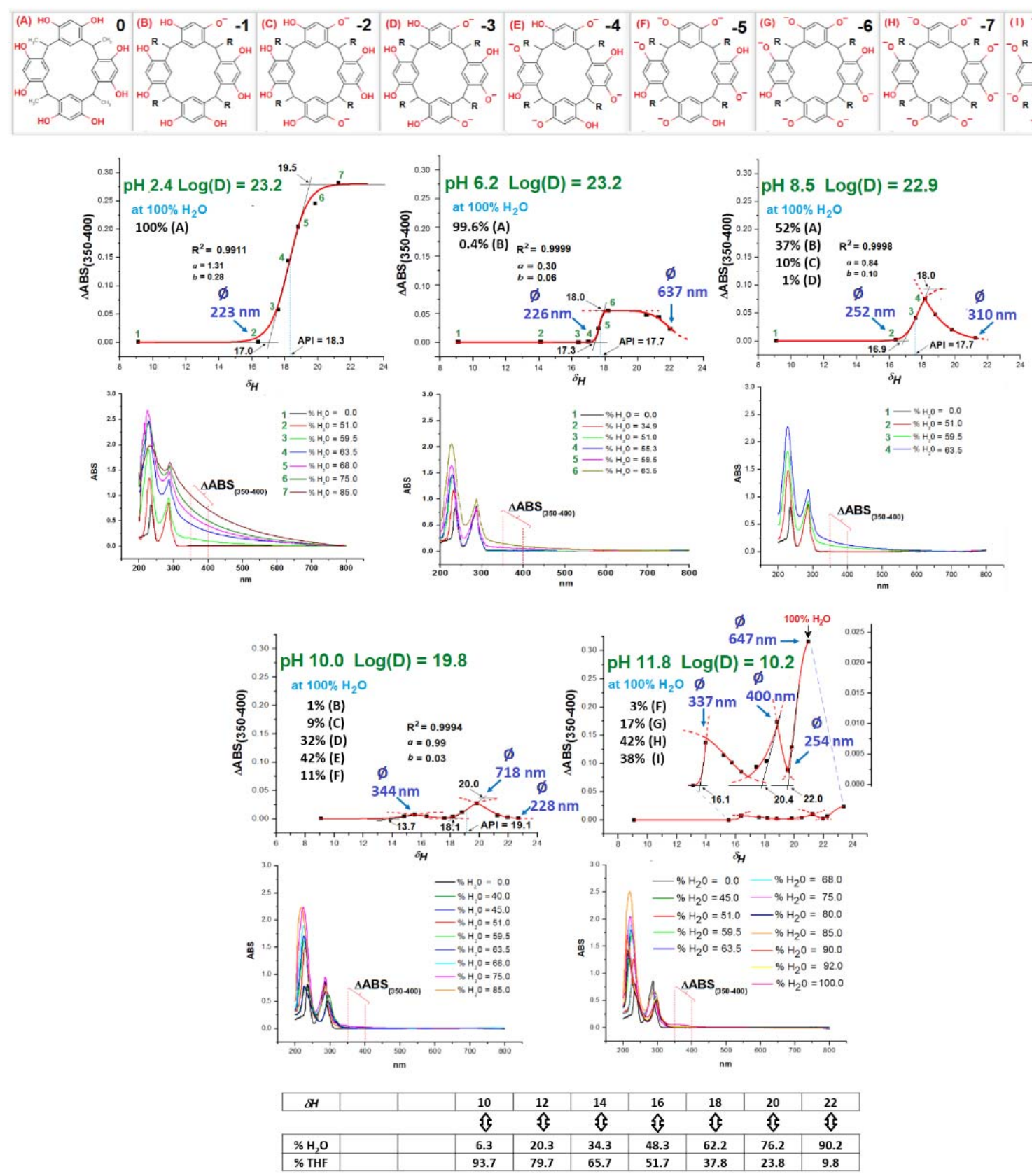

Figure 8. The sigmoidal aggregation profiles and the corresponding UV-visible spectra of resorc[4]arene R3 as obtained in $\mathrm{THF}$ / water solvent systems at fixed $\mathrm{pH}$ values of the aqueous component. Regression analysis to fit the experimental data was performed according to Equation (2). Subfigures (A-I) represent the deprotonation states of $\mathbf{R} \mathbf{3}$ at the analyzed $\mathrm{pH}$ values of 2.4,6.2, 8.5, 10.0 and 11.8 (the relevant percentages are shown next to the respective aggregation plots). 


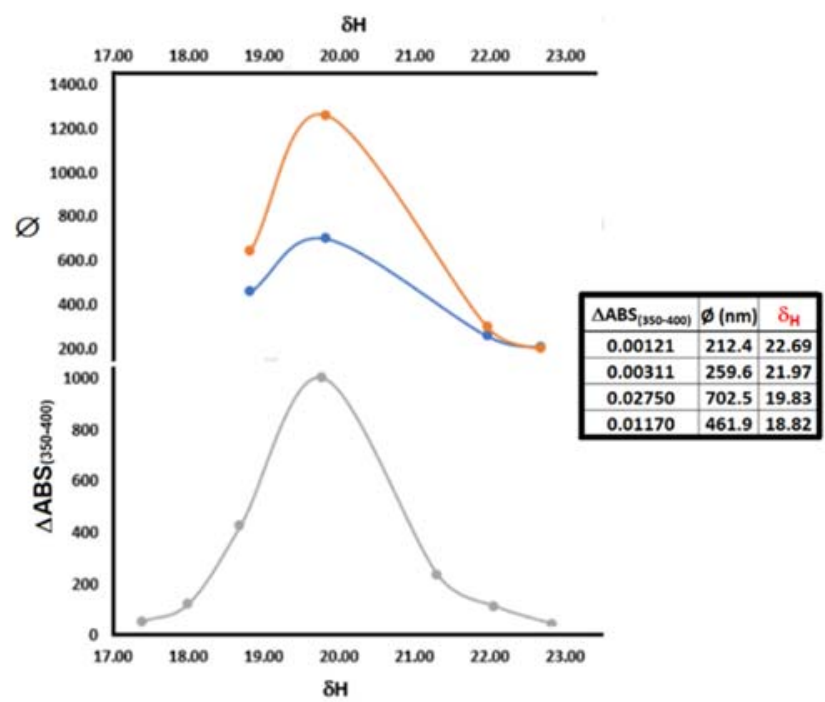

Figure 9. DLS profiles of $\mathbf{R} 3$ aggregates in solutions prepared from a THF/(buffer- $\left.\mathrm{pH}_{10.0}\right)$ mixture: variation of $\varnothing$ (blue) related to the $\Delta \mathbf{A B S}_{\mathbf{3 5 0}-\mathbf{4 0 0}}$ changes at the same $\delta_{\mathbf{H}}$ range (gray); variation of $\varnothing$ (orange) after one hour.

\subsection{Lyophilic Colloids Based on Self-Aggregated Resorc[4]arenes $\mathbf{R} 2$ and $\mathbf{R} \mathbf{3}$}

The ability of lyophilic colloids based on resorc[4]arenes $\mathbf{R} \mathbf{2}$ and $\mathbf{R} 3$ to capture hydrophobic compounds in wide polar media was investigated towards Glabrescione B $(\mathrm{GlaB}, \log (\mathrm{D})=5.14)$ (Figure 9), a naturally-occurring isoflavone which proved to be a good preclinical candidate for the treatment of Hedgehog $(\mathrm{Hh})$ dependent tumors [41-44]. Based on the above-mentioned results, the self-aggregation process of $\mathbf{R} \mathbf{2}$ was induced in its completely deprotonated form by using a THF/(buffer- $\left.\mathrm{pH}_{8.7}\right)$ mixture at $\boldsymbol{\delta}_{\mathbf{H}}$ values of 21.97 and 22.69 (corresponding to $90 \%$ and $95 \%$ of water composition, respectively). As showed in Figure 10, while GlaB alone gives rise to cloudy suspensions in both selected $\boldsymbol{\delta}_{\mathbf{H}}$ conditions, by using the $\mathbf{R} \mathbf{2}$ lyophilic colloids, the turbidity, although present, appears strongly reduced.
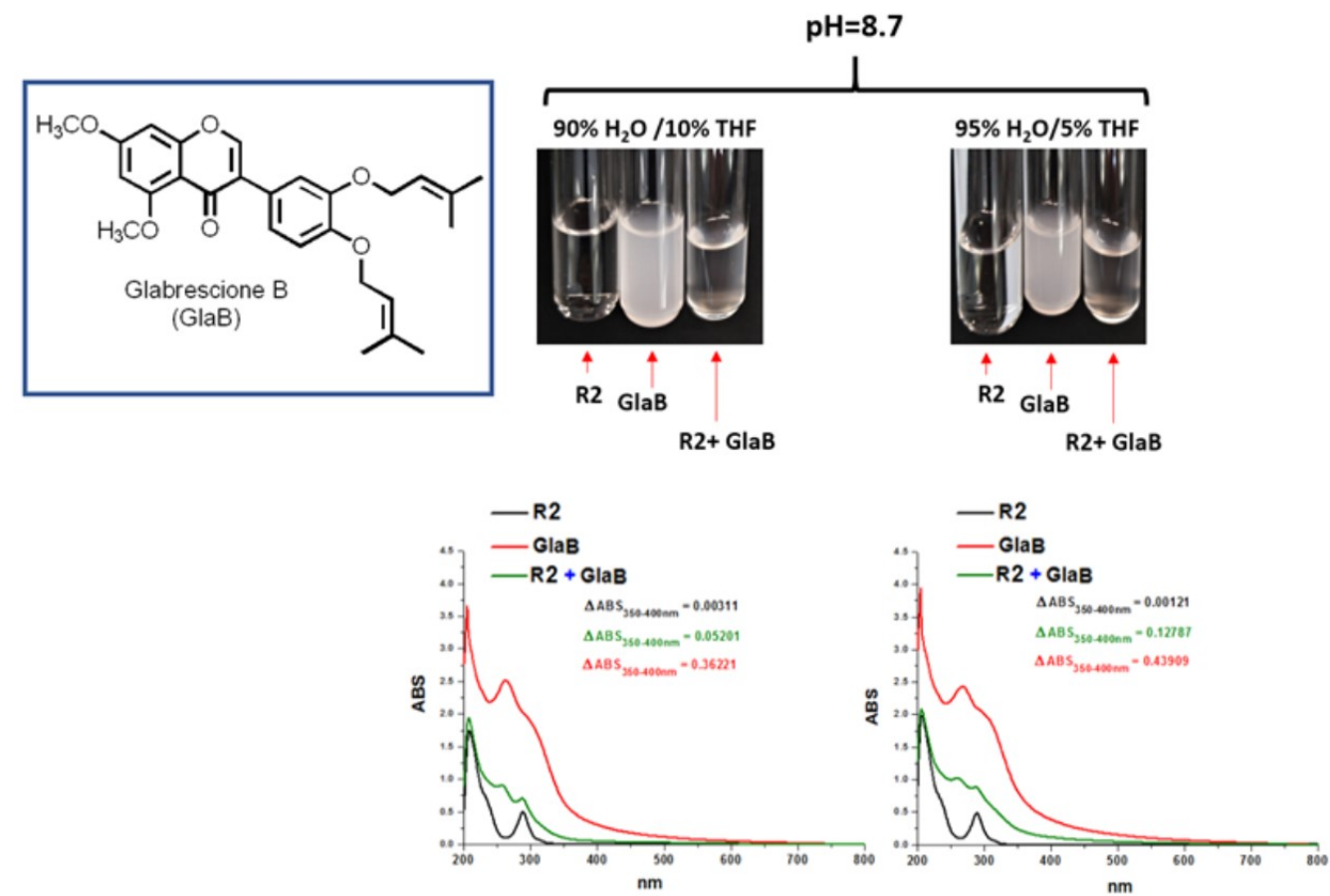

Figure 10. The ability of lyophilic colloids based on resorc[4] arene $\mathbf{R} 2$ to encapsulate GlaB by using a $\mathrm{THF} /\left(\right.$ buffer-pH $\mathrm{p}_{8.7}$ ) mixture at different $\boldsymbol{\delta}_{\mathbf{H}}$ values. 
The observed behavior of resorc[4]arene $\mathbf{R} 3$ was rather different. The aggregation test of GlaB alone and in the presence of $\mathbf{R} 3$ was performed by employing THF/buffer mixtures featuring different $\delta_{\mathbf{H}}$ values: (a) 19.83, 21.97, and 22.69, with the use of buffer$\mathrm{pH}_{10.0}$ solution; (b) 21.97 and 22.69, with the use of buffer- $\mathrm{pH}_{11.8}$ solution. As outlined in Figure 11, by using an equimolar concentration of GlaB and R3 $\left(3.0 \times 10^{-5} \mathrm{M}\right)$, clear colloidal solutions at both the analyzed $\mathrm{pH}$ values were obtained. Coherently, the aggregate dimensions established by the DLS measurements indicate that the lyophilic colloids $(\mathbf{R} 3+\mathrm{GlaB})$ at $\delta_{\mathbf{H}}=22.69$ reach diameters very close to the ones measured for the selfaggregated $\mathbf{R} 3$, at both the $\mathrm{pH}$ values of 10.0 and 11.8. In addition, the dimensional stability of lyophilic colloids $(\mathbf{R} 3+\mathrm{GlaB})$ in the THF $/\left(\right.$ buffer- $\left.\mathrm{pH}_{11.8}\right)$ solvent system at $\boldsymbol{\delta}_{\mathbf{H}}=22.69$ was analyzed over time by DLS measurements (Figure 11). The R3-GlaB aggregates were stable within the first hour (h), characterized by a diameter of $276 \mathrm{~nm}$. Later ( $4 \mathrm{~h}$ ), a reduction occurred, reaching a $\delta$ of $136 \mathrm{~nm}$, and a further increment towards the value of $400 \mathrm{~nm}$ was observed within $24 \mathrm{~h}$.
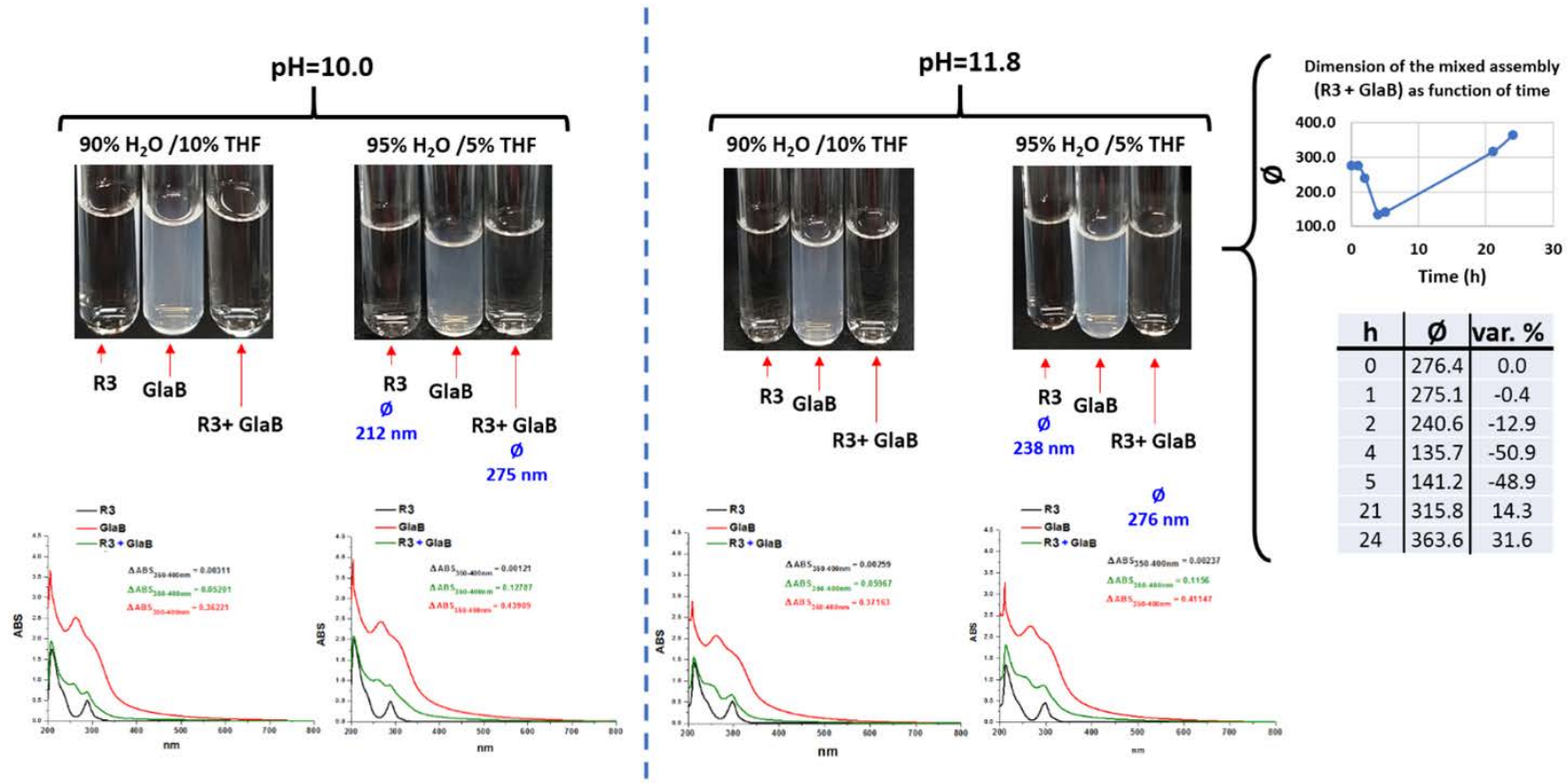

Figure 11. The ability of lyophilic colloids based on resorc[4]arene $\mathbf{R} 3$ to act as a molecular shuttle of GlaB by using $\mathrm{THF} /\left(\right.$ buffer-pH $\mathrm{H}_{10.0}$ ) and THF/(buffer- $\mathrm{pH}_{11.8}$ ) mixtures at different $\boldsymbol{\delta}_{\mathbf{H}}$ values.

\section{Materials and Methods}

\subsection{Synthesis of Resorc[4]arenes}

General remarks: melting points were recorded with a Büchi melting point B-545 and are not corrected. The ${ }^{1} \mathrm{H}$ and ${ }^{13} \mathrm{C}$ NMR spectra have been acquired with a Bruker Avance 400 spectrometer operating at 400.13 and $100.6 \mathrm{MHz}$, respectively, at $300 \mathrm{~K}$ in $\mathrm{CDCl}_{3}$ or DMSO- $\mathrm{d}_{6}$, using $5 \mathrm{~mm}$ diameter glass tubes. Chemical shifts were expressed in ppm and coupling constants $(\mathrm{J})$ in hertz $(\mathrm{Hz})$, approximated to $0.1 \mathrm{~Hz}$. The residual solvent peak was used as an internal reference for ${ }^{1} \mathrm{H}$ and ${ }^{13} \mathrm{C}$ NMR spectra. Data for ${ }^{1} \mathrm{H}$ NMR are reported as follows: chemical shift, multiplicity $(\mathrm{br}=$ broad, ovrlp = overlapped, $\mathrm{s}=$ singlet, $\mathrm{d}=$ doublet, $\mathrm{t}=$ triplet, $\mathrm{q}=$ quartet, $\mathrm{m}=$ multiplet, $\mathrm{dd}=$ double doublet), coupling constant, and integral. Spectra were processed with the program MestReNova version 6.0.2-5475, FT and zero filling at $64 \mathrm{~K}$. High-resolution (HR) mass spectra were obtained using a Thermo Fischer Exactive mass spectrometer equipped with an ESI source and an Orbitrap analyzer: capillary temperature $275^{\circ} \mathrm{C}$, spray voltage $3.5 \mathrm{kV}$, sheath gas $\left(\mathrm{N}_{2}\right) 10$ arbitrary units, capillary voltage $65 \mathrm{~V}$, and tube lens $125 \mathrm{~V}$. Analytical TLC were performed using $0.25 \mathrm{~mm}$ Fluka F254 silica gel. The compounds on TLC were revealed by quenching fluorescence (at 254 and $365 \mathrm{~nm}$ ) using a $4 \mathrm{~W}$ UV lamp. Otherwise, plates were stained 
with an acidic solution of p-anisaldehyde or a $10 \%$ phosphomolybdic acid solution in $\mathrm{EtOH}$ and heated $\left(\mathrm{T}=120^{\circ} \mathrm{C}\right)$. The product mixture purifications were carried out with silica column chromatography using Fluka 60 A silica gel (0063-0200 mm, 70-230 mesh). Flash chromatography was performed using 200-400 mesh silica gel. Commercially available reagents were supplied by Sigma-Aldrich and used without further purification. Dry solvents were purchased from Sigma-Aldrich or dried by distillation. Resorcarene R3 $[37,38]$ and GlaB $[45]$ were synthesized according to the literature. Yields of synthesized compounds are referred to chromatographically and spectroscopically pure compounds, unless otherwise stated.

\subsection{Synthesis of Tetraundecanyl Tetra-O-methyl Resorc[4]arene (3)}

Boron trifluoride etherate $(2.3 \mathrm{~g}, 2 \mathrm{~mL}, 16.2 \mathrm{mmol})$ was added to a solution of 3methoxyphenol (1) $(1 \mathrm{~g}, 0.88 \mathrm{~mL}, 8.0 \mathrm{mmol})$ and dodecanal $(2)(1.47 \mathrm{~g}, 1.76 \mathrm{~mL}, 8.0 \mathrm{mmol})$ in anhydrous dichloromethane $(40 \mathrm{~mL})$, and the reaction was kept under stirring at room temperature for $2 \mathrm{~h}$. The reaction mixture was then washed with water $(2 \times 40 \mathrm{~mL})$ and brine $(1 \times 40 \mathrm{~mL})$. The organic layer was dried over anhydrous $\mathrm{Na}_{2} \mathrm{SO}_{4}$, and the solvent was removed under reduced pressure to give a dark red oil. The crude was crystalized from hot ethanol to give a reddish solid. The product was recrystallized from hot methanol to obtain pure compound $3\left(0.687 \mathrm{~g}, 80 \%\right.$ yield) as a pale pinkish solid. ${ }^{1} \mathrm{H}$ NMR $(400 \mathrm{MHz}$, $\left.\mathrm{CDCl}_{3}\right) \delta 7.51(\mathrm{~s}, 4 \mathrm{H}), 7.22(\mathrm{~s}, 4 \mathrm{H}), 6.35(\mathrm{~s}, 4 \mathrm{H}), 4.27(\mathrm{t}, \mathrm{J}=7.4 \mathrm{~Hz}, 4 \mathrm{H}), 3.83(\mathrm{~s}, 12 \mathrm{H}), 2.19(\mathrm{~d}$, $\mathrm{J}=6.7 \mathrm{~Hz}, 8 \mathrm{H}), 1.27(\mathrm{M}, 72 \mathrm{H})$, and $0.89(\mathrm{t}, \mathrm{J}=6.3 \mathrm{~Hz}, 12 \mathrm{H}) ;{ }^{13} \mathrm{C} \mathrm{NMR}\left(101 \mathrm{MHz}, \mathrm{CDCl}_{3}\right) \delta$ 153.7, 153.1, 124.9, 124.7, 123.8, 100.1, 77.5, 77.2, 76.8, 56.0, 34.1, 33.2, 32.1, 29.9, 29.9, 29.6, $28.2,22.8$, and 14.3 .

\subsection{Synthesis of Tetraundecanyl-tetra(methoxycarbonylmethoxyl)-tetra-O-methyl Resorc[4]arene (R1)}

Methyl bromoacetate $(0.225 \mathrm{~mL}, 0.364 \mathrm{~g}, 2.38 \mathrm{~mol})$ was added to a stirred solution of resorc[4]arene $3(0.554 \mathrm{~g}, 0.476 \mathrm{mmol})$ and $\mathrm{K}_{2} \mathrm{CO}_{3}(0.654 \mathrm{~g}, 4.76 \mathrm{mmol})$ in dry acetonitrile $(65 \mathrm{~mL})$, and the reaction mixture was heated at reflux for $24 \mathrm{~h}$ under inert atmosphere. Then, the reaction mixture was cooled down and the solvent was removed under reduced pressure. The residue was dissolved in dichloromethane $(40 \mathrm{~mL})$, and the organic layer was washed with $1 \mathrm{M} \mathrm{HCl}(10 \mathrm{~mL})$, with water and brine. The organic layer was dried over anhydrous $\mathrm{Na}_{2} \mathrm{SO}_{4}$, and the solvent was removed under reduced pressure. The pure product $\mathbf{R} 1$ was obtained as a solid $(0.398 \mathrm{~g}, 0.274 \mathrm{mmol})$ in $58 \%$ yield and used without further purification. ${ }^{1} \mathrm{H}$ NMR $\left(400 \mathrm{MHz}, \mathrm{CDCl}_{3}\right) \delta 6.61(\mathrm{~s}, 4 \mathrm{H}), 6.29(\mathrm{~s}, 4 \mathrm{H}), 4.50$ $(\mathrm{t}, \mathrm{J}=7.4 \mathrm{~Hz}, 4 \mathrm{H}), 4.21(\mathrm{~d}, \mathrm{~J}=15.9 \mathrm{~Hz}, 4 \mathrm{H}), 4.02(\mathrm{~d}, \mathrm{~J}=15.9 \mathrm{~Hz}, 4 \mathrm{H}), 3.77(\mathrm{~s}, 12 \mathrm{H}), 3.61(\mathrm{~s}$, $\mathrm{J}=5.5 \mathrm{~Hz}, 12 \mathrm{H}), 1.85-1.77(\mathrm{~m}, 8 \mathrm{H}), 1.32-1.21($ ovrlp m, $18 \mathrm{H})$, and $0.87(\mathrm{t}, \mathrm{J}=6.9 \mathrm{~Hz}, 12 \mathrm{H})$; ${ }^{13} \mathrm{C}$ NMR $\left(101 \mathrm{MHz}, \mathrm{CDCl}_{3}\right) \delta 170.3,155.7,155.0,128.4,127.6,126.5,99.7,77.5,77.2,76.8$, $68.4,55.6,52.0,50.9,35.6,34.8,32.1,30.1,30.0,29.9,29.87,29.83,29.5,28.2,22.8$, and 14.2.

\subsection{Synthesis of Tetraundecanyl-tetra(hydroxycarbonylmethoxyl)-tetra-O-methyl Resorc[4]arene (R2)}

A $2 \mathrm{M}$ aqueous solution of potassium hydroxide $(15 \mathrm{~mL})$ was added to a solution of resorc[4]arene $\mathbf{R} \mathbf{1}(0.400 \mathrm{~g}, 0.276 \mathrm{mmol})$ in THF $(40 \mathrm{~mL})$, and the reaction mixture was stirred for $24 \mathrm{~h}$ at room temperature. Then the solution was acidified with $2 \mathrm{M} \mathrm{HCl}(40 \mathrm{~mL})$ and the THF was removed under reduced pressure. The white precipitate was filtered, washed with water, and dried under a vacuum at $80^{\circ} \mathrm{C}$ for $3 \mathrm{~h}$. Then it was dissolved in THF and the solution was filtered. The THF was removed under reduced pressure to give $\mathbf{R} 2$ as a white powder $(0.366 \mathrm{~g}, 0.262 \mathrm{mmol})$ in $95 \%$ yield. ${ }^{1} \mathrm{H}$ NMR $(400 \mathrm{MHz}$, DMSO-d $\left._{6}\right) \delta 6.65(\mathrm{~s}, 4 \mathrm{H}), 6.38(\mathrm{~s}, 4 \mathrm{H}), 4.51(\mathrm{t}, \mathrm{J}=7.0 \mathrm{~Hz}, 4 \mathrm{H}), 4.42(\mathrm{~d}, \mathrm{~J}=16.1 \mathrm{~Hz}, 4 \mathrm{H}), 4.25$ $(\mathrm{d}, \mathrm{J}=16.1 \mathrm{~Hz}, 4 \mathrm{H}), 3.57(\mathrm{~s}, 12 \mathrm{H}), 1.69(\mathrm{br} \mathrm{s}, 8 \mathrm{H}), 1.16(\mathrm{~s}, 72 \mathrm{H})$, and $0.79(\mathrm{t}, \mathrm{J}=6.7 \mathrm{~Hz}, 12 \mathrm{H})$. ${ }^{13} \mathrm{C}$ NMR $\left(101 \mathrm{MHz}\right.$, DMSO-d $\left._{6}\right) \delta$ 170.50, 155.23, 154.27, 125.88, 125.30, 125.23, 98.43, 66.47, 55.47, 35.05, 34.11, 31.40, 30.69, 29.58, 29.35, 29.19, 28.84, 27.62, 22.14, and 13.82. ESI-HRMS: $m / z[\mathrm{M}-\mathrm{H}]^{-} \mathrm{C}_{84} \mathrm{H}_{127} \mathrm{O}_{16}$ requires 1391.9130, found 1391.9100; $[\mathrm{M}-2 \mathrm{H}]^{-2} \mathrm{C}_{84} \mathrm{H}_{126} \mathrm{O}_{16}$ 
requires 695.4528, found 695.4524; and $[\mathrm{M}-3 \mathrm{H}]^{-3} \mathrm{C}_{84} \mathrm{H}_{125} \mathrm{O}_{16}$ requires 463.2995, found 463.2993.

\subsection{UV-Vis Spectroscopical Analyses}

General remarks: all spectroscopic analyses were performed with the JASCO V-550 spectrometer with a Peltier thermostat at $25{ }^{\circ} \mathrm{C}$ using a quartz cuvette (cell length $1 \mathrm{~mm}$ ). The HPLC grade THF (tetrahydrofuran) and $\mathrm{H}_{2} \mathrm{O}$ (water) were obtained from Sigma Aldrich, St. Louis, MO, USA.

\subsection{Preparation of Solutions}

Stock solution of R1 $\left(\mathrm{C}_{88} \mathrm{H}_{136} \mathrm{O}_{16}, \mathrm{Mw} 1449.76 \mathrm{~g} / \mathrm{mol} ; 6.1 \times 10^{-3} \mathrm{~g}, 4.2 \times 10^{-3} \mathrm{mmol}\right)$ at a concentration of $2.1 \times 10^{-4} \mathrm{M}$ in $20 \mathrm{~mL}$ of THF was prepared. Starting from this solution, the samples used for the UV spectrophotometric analysis were obtained with a different THF $/ \mathrm{H}_{2} \mathrm{O}$ ratio (from $0 \%$ to $85 \%$ of water) having a final concentration of $\mathbf{R} 1$ equal to $3.2 \times 10^{-5} \mathrm{M}$ and a final volume of $2 \mathrm{~mL}$. The baseline was obtained with the same $\mathrm{THF} / \mathrm{H}_{2} \mathrm{O}$ ratio as the samples. Stock solution of $\mathbf{R} 2\left(\mathrm{C}_{84} \mathrm{H}_{128} \mathrm{O}_{16}, \mathrm{Mw} 1392.92 \mathrm{~g} / \mathrm{mol}\right.$; $5.6 \times 10^{-3} \mathrm{~g}, 4.0 \times 10^{-3} \mathrm{mmol}$ ) at a concentration of $2.0 \times 10^{-4} \mathrm{M}$ in $20 \mathrm{~mL}$ of THF was prepared. Starting from this solution, the samples used for the UV spectrophotometric analysis were obtained with a different THF $/ \mathrm{H}_{2} \mathrm{O}$ ratio (from $0 \%$ to $85 \%$ of water) having a final concentration of $\mathbf{R} 2$ equal to $3.0 \times 10^{-5} \mathrm{M}$ and a final volume of $2 \mathrm{~mL}$. The baseline was obtained with the same THF $/ \mathrm{H}_{2} \mathrm{O}$ ratio as the samples. Modifications of the $\mathrm{pH}$ were obtained by using an aqueous solution of phosphate buffer $\left(\mathrm{NaH}_{2} \mathrm{PO}_{4}\right.$, $\mathrm{Mw} 119.98 \mathrm{~g} / \mathrm{mol}, 8.2 \times 10^{-3} \mathrm{~g}$ in $50 \mathrm{~mL}$ of $\mathrm{H}_{2} \mathrm{O}, 10^{-3} \mathrm{M}$ and $\mathrm{H}_{3} \mathrm{PO}_{4}, \mathrm{Mw} 97.99 \mathrm{~g} / \mathrm{mol}$ ) at a different ratio. The baseline was obtained with the same THF/buffer phosphate ratio as the samples. Stock solution of $\mathbf{R} 3\left(\mathrm{C}_{72} \mathrm{H}_{112} \mathrm{O}_{8}, \mathrm{Mw} 1105.65 \mathrm{~g} / \mathrm{mol} ; 10.5 \times 10^{-3} \mathrm{~g}\right.$, $9.5 \times 10^{-3} \mathrm{mmol}$ ) at a concentration of $1.9 \times 10^{-4} \mathrm{M}$ in $20 \mathrm{~mL}$ of THF was prepared. Starting from this solution, the samples used for the UV spectrophotometric analysis were obtained with a different $\mathrm{THF} / \mathrm{H}_{2} \mathrm{O}$ ratio (from $0 \%$ to $85 \%$ of water) having a final concentration of $\mathbf{R} 3$ equal to $2.85 \times 10^{-5} \mathrm{M}$ and final volume of $2 \mathrm{~mL}$. The baseline was obtained with the same THF $/ \mathrm{H}_{2} \mathrm{O}$ ratio as the samples. Modifications of the $\mathrm{pH}$ at 11.78 were obtained by an aqueous solution of sodium tetraborate decahydrate $\left(\mathrm{Na}_{2} \mathrm{~B}_{2} \mathrm{O}_{7} \cdot 10 \mathrm{H}_{2} \mathrm{O}, \mathrm{Mw} 381.49 \mathrm{~g} / \mathrm{mol}, 5.63 \times 10^{-2} \mathrm{~g}\right.$ in $100 \mathrm{~mL}$ of $\left.\mathrm{H}_{2} \mathrm{O}, 1.5 \times 10^{-3} \mathrm{M}\right)$ and sodium hydroxide $(\mathrm{NaOH}, \mathrm{Mw} 39.99 \mathrm{~g} / \mathrm{mol}, 1 \mathrm{~N})$. The baseline was obtained with the same THF/buffer borate ratio as the samples. A stock solution of $\mathrm{GlaB}\left(\mathrm{C}_{27} \mathrm{H}_{30} \mathrm{O}_{6}\right.$, $\mathrm{Mw}$ $450.5 \mathrm{~g} / \mathrm{mol} ; 3.6 \times 10^{-3} \mathrm{~g}, 8.0 \times 10^{-3} \mathrm{mmol}$ ) of $4 \times 10^{-4} \mathrm{M}$ in $20 \mathrm{~mL}$ of THF was prepared. Starting from this solution, the samples were diluted in THF in a ratio of 1:2 (final concentration $2 \times 10^{-4} \mathrm{M}$ ) and used for the UV spectrophotometric analysis were obtained with a different THF/buffer phosphate $(\mathrm{pH} 11.82$ ) ratio (from $0 \%$ to $85 \%$ of water) having a final concentration of GlaB equal to $3.0 \times 10^{-5} \mathrm{M}$ and a final volume of $2 \mathrm{~mL}$. The baseline was obtained with the same THF/buffer phosphate ratio as the samples. Stock solution of guest (GlaB) and host (R3) in a ratio of 1:1 was prepared in THF. Starting from this solution, the samples that were used for the UV spectrophotometric analysis were obtained with a different THF/buffer phosphate $(\mathrm{pH} 11.85$ ) ratio (from $0 \%$ to $85 \%$ of water) having a final concentration of GlaB and R3 equal to $3.0 \times 10^{-5} \mathrm{M}$ and a final volume of $2 \mathrm{~mL}$. The baseline was obtained with the same THF/buffer phosphate ratio as the samples. Starting from the stock solutions of $\mathbf{R} 3$ and GlaB at a concentration of $1.2 \times 10^{-3} \mathrm{M}, 0.100 \mathrm{~mL}$ of sample was taken and solubilized in $0.100 \mathrm{~mL}$ of THF and $1.8 \mathrm{~mL}$ of buffer to obtain the concentration of water at $90 \%$. A $0.100 \mathrm{~mL}$ of solubilized sample in $1.9 \mathrm{~mL}$ of buffer was used to obtain a $95 \%$ water concentration. In both cases the sample had a concentration of $6 \times 10^{-5} \mathrm{M}$. A $1 \mathrm{~mL}$ of solution of $\mathbf{R} 3$ was added to a $1 \mathrm{~mL}$ of solution of GlaB to give a final volume of $2 \mathrm{~mL}$, with a final equimolar concentration of the compounds equal to $3 \times 10^{-5} \mathrm{M}$. 


\subsection{DLS Analysis}

The size and $\mathrm{z}$ potential values of resorc[4]arene $\mathbf{R} 3$ were measured by using a 90Plus/BI-MAS ZetaPlus multiangle particle size analyzer (Brookhaven Instruments Corp., Holtsville, NY, USA). For size measurements, the autocorrelation function of the scattered light was analyzed assuming a log Gaussian distribution of the vesicle size. The mean size and polydispersity index have been obtained. The z potential values were calculated from the electrophoretic mobility by means of the Helm-holtz-Smoluchowski relationship.

\section{Conclusions}

In conclusion, we carried out a detailed characterization of the self-assembly process of amphiphilic resorc[4]arene-based architectures featuring long aliphatic side chains and a different pattern of substitution on the upper rim, including functional groups able to undergo acid dissociation. Based on the hydrophilic features and the ionization properties of the upper rim of the macrocycles, these amphiphiles revealed a strong propensity to self-assembly in a specific THF/water composition. The combination of theoretical calculations with the experimental results highlighted that the supramolecular assembly of ionizable resorc[4]arenes is strictly dependent on the $\mathrm{pH}$ values, when using solutions largely rich in water (i.e., $10 \% \mathrm{THF} / 90 \% \mathrm{H}_{2} \mathrm{O}$ and $5 \% \mathrm{THF} / 95 \% \mathrm{H}_{2} \mathrm{O}$ ), leading to the formation of lyophilic colloids with characteristic diameters. Based on these properties, we demonstrated that the resorc[4]arene-based systems can entrap the poorly water-soluble isoflavone GlaB, most probably due to inclusion complexation between the guest molecules and the hydrophobic alkyl chains of the macrocycles. The next steps of the study will be: (i) the NMR investigation to characterize the inclusion complexation more deeply; (ii) the design of novel amphiphilic architectures featuring ionizable functional groups with improved ability to supramolecular self-assemble in water at specific $\mathrm{pH}$ values. In addition, we will investigate the in vitro bioactivity of GlaB-resorcarene aggregates in the anticancer efficiency towards the Hh-dependent tumors.

Supplementary Materials: The following are available online at https:/ / www.mdpi.com/article/10 $.3390 /$ ijms222111785/s1, Figure S1: $\mathrm{pH}$ variations of THF/water solutions depending on the mixture composition and different prefixed $\mathrm{pH}$ values, Figure S2: ${ }^{1} \mathrm{H} \mathrm{NMR}$ spectrum of compound $3\left(\mathrm{CDCl}_{3}\right.$, $400 \mathrm{MHz})$, Figure S3: ${ }^{13} \mathrm{C}$ NMR spectrum of compound $3\left(\mathrm{CDCl}_{3}, 101 \mathrm{MHz}\right)$, Figure S4: ${ }^{1} \mathrm{H} \mathrm{NMR}$ spectrum of compound R1 $\left(\mathrm{CDCl}_{3}, 400 \mathrm{MHz}\right)$, Figure S5: ${ }^{13} \mathrm{C}$ NMR spectrum of compound R1 $\left(\mathrm{CDCl}_{3}, 101 \mathrm{MHz}\right)$, Figure S6: ${ }^{1} \mathrm{H}$ NMR spectrum of compound R2 (DMSO- $\left.\mathrm{d}_{6}, 400 \mathrm{MHz}\right)$, Figure S7: ${ }^{13} \mathrm{C}$ NMR spectrum of compound R2 (DMSO- $\left.\mathrm{d}_{6}, 101 \mathrm{MHz}\right)$, Figure S8: ESI-HRMS spectrum of compound R2, Table S1: $\mathbf{R} 3$ pH 9.96 from $68 \%$ to $95 \% \mathrm{H}_{2} \mathrm{O}$, Table S2: $\mathbf{R} 3+\mathrm{GlaB}$ pH $11.8,95 \% \mathrm{H}_{2} \mathrm{O}$, Table S3: R1, Table S4: R2 pH 6.21, Table S5: R2 pH 1.91, Table S6: R2 pH 8.70, Table S7: R3 pH 6.21, Table S8: R3 pH 2.41, Table S9: R3 pH 8.52, Table S10: R3 pH 10.0, Table S11: R3 pH 11.8.

Author Contributions: F.B. performed the UV-vis studies. F.G., I.R. and A.C. contributed to analyze the data and fully reviewed the manuscript. M.P. and D.Q. design the experiments, analyze the data, and fully reviewed the manuscript. G.S. and S.P. performed DLS analysis. M.P. and B.B. conceived the project and provided overall guidance. The manuscript was written with contribution of all authors. All authors have read and agreed to the published version of the manuscript.

Funding: This research was funded by MIUR (Art. 1, commi 314-337 Legge 232/2016) for the Excellence Departments grant to the Department of Chemistry and Technology of Drugs, and by PON (Piano Operativo Nazionale) Grant ARS01_00432 PROGEMA, “Processi Green per l'Estrazione di Principi Attivi e la Depurazione di Matrici di Scarto e Non", March 2018-September 2020.

Institutional Review Board Statement: Not applicable.

Informed Consent Statement: Not applicable.

Data Availability Statement: Not applicable.

Acknowledgments: We acknowledge the COST Action CM1407 networking "Challenging Organic Syntheses Inspired by Nature-From Natural Products Chemistry to Drug Discovery". We gratefully acknowledge Claudio Villani and Roberta Franzini for the ESI-HRMS analysis. 
Conflicts of Interest: The authors declare no conflict of interest.

Notes: This manuscript is dedicated to Professor Maurizio Botta.

\section{References}

1. Wang, C.; Wang, Z.; Zhang, X. Amphiphilic building blocks for self-assembly: From amphiphiles to supra-amphiphiles. Acc. Chem. Res. 2012, 45, 608-618. [CrossRef]

2. Helttunen, K.; Shahgaldian, P. Self-assembly of amphiphilic calixarenes and resorcinarenes in water. Acc. Chem. Res. 2010, 34, 2704-2714. [CrossRef]

3. Guldi, D.M.; Hungerbuehler, H.; Asmus, K.D.J. Redox and excitation studies with C60-substituted malonic acid diethyl esters. J. Phys. Chem. 1995, 99, 9380-9385. [CrossRef]

4. Fox, O.D.; Cookson, J.; Wilkinson, E.J.; Drew, M.G.; MacLean, E.J.; Teat, S.J.; Beer, P.D. Nanosized polymetallic resorcinarene-based host assemblies that strongly bind fullerenes. J. Am. Chem. Soc. 2006, 128, 6990-7002. [CrossRef]

5. Flídrová, K.; Liška, A.; Ludvík, J.; Eigner, V.; Lhoták, P. Fullerene recognition by 5-nitro-11, 17, 23, 29-tetramethylcalix [5] arene. Tethraedron Lett. 2015, 56, 1535-1538. [CrossRef]

6. García-Simón, C.; Costas, M.; Ribas, X. Metallosupramolecular receptors for fullerene binding and release. Chem. Soc. Rev. 2016, 45, 40-62. [CrossRef] [PubMed]

7. Atwood, J.L.; Koutsantonis, G.A.; Raston, C.L. Purification of $C 60$ and C 70 by selective complexation with calixarenes. Nature 1994, 368, 229-231. [CrossRef]

8. Suzuki, T.; Nakashima, K.; Shinkai, S. Very Convenient and Efficient Purification Method for Fullerene (C60) with 5, 11, 17, 23, 29, 35, 41, 47-Octa-tert-butylcalix [8] arene-49, 50, 51, 52, 53, 54, 55, 56-octol. Chem. Lett. 1994, 23, 699-702. [CrossRef]

9. Chen, X.; Boulos, R.A.; Slattery, A.D.; Atwood, J.L.; Raston, C.L. Unravelling the structure of the $\mathrm{C}_{60}$ and p-But-calix [8] arene complex. Chem. Comm. 2015, 51, 11413-11416. [CrossRef]

10. Araki, K.; Akao, K.; Ikeda, A.; Suzuki, T.; Shinkai, S.I. Molecular design of calixarene-based host molecules for inclusion of C60 in solution. Tethraedron Lett. 1996, 37, 73-76. [CrossRef]

11. Grimm, B.; Santos, J.; Illescas, B.M.; Munoz, A.; Guldi, D.M.; Martin, N. A new exTTF-crown ether platform to associate fullerenes: Cooperative $n-\pi$ and $\pi-\pi$ effects. J. Am. Chem. Soc. 2010, 132, 17387-17389. [CrossRef]

12. Wang, H.M.; Wenz, G. Molecular solubilization of fullerene $\mathrm{C} 60$ in water by $\gamma$-cyclodextrin thioethers. J. Org. Chem. 2012, 8 , 1644-1651. [CrossRef] [PubMed]

13. Moreira, L.; Calbo, J.; Calderon, R.M.K.; Santos, J.; Illescas, B.M.; Aragó, J.; Nierengarten, J.-F.; Guldi, D.M.; Ortí, E.; Martín, N. Unveiling the nature of supramolecular crown ether-C 60 interactions. Chem. Sci. 2015, 6, 4426-4432. [CrossRef]

14. Neri, P.; Sessler, J.L.; Wang, M.X. Calixarenes and Beyond; Springer International Publishing: Basel, Switzerland, 2016.

15. Hoskins, C.; Curtis, A.D. Simple calix [n] arenes and calix [4] resorcinarenes as drug solubilizing agents. J. Nanomed. Res. 2015, 2, 00028 .

16. Bayrakc1, M.; Ertul, Ş.; Yılmaz, M. Solubilizing effect of the p-phosphonate calix [n] arenes towards poorly soluble drug molecules such as nifedipine, niclosamide and furosemide. J. Incl. Phenom. Macrocycl. Chem. 2012, 74, 415-423. [CrossRef]

17. Bayrakc1, M.T.; Ertul, S.; Yilmaz, M. Phase solubility studies of poorly soluble drug molecules by using O-phosphorylated calixarenes as drug-solubilizing agents. J. Chem. Eng. Data 2012, 57, 233-239. [CrossRef]

18. Niikura, K.; Anslyn, E.V. Azacalixarene: Synthesis, conformational analysis, and recognition behavior toward anions. J. Chem. Soc. 1999, 12, 2769-2775. [CrossRef]

19. Almi, M.; Arduini, A.; Casnati, A.; Pochini, A.; Ungaro, R. Chloromethylation of calixarenes and synthesis of new water soluble macrocyclic hosts. Tethraedron 1989, 45, 2177-2182. [CrossRef]

20. Gutsche, C.D.; Alam, I. Calixarenes. 23. The complexation and catalytic properties of water soluble calixarenes. Tethraedron 1988, 44, 4689-4694. [CrossRef]

21. Shinkai, S.; Kawabata, H.; Matsuda, T.; Kawaguchi, H.; Manabe, O. Synthesis and Inclusion Properties of "Neutral” Water-Soluble Calixarenes. Bull. Chem. Soc. Jpn. 1990, 63, 1272-1274. [CrossRef]

22. Marra, A.; Scherrmann, M.C.; Dondoni, A.; Ungaro, R.; Casnati, A.; Minari, P. Sugar Calixarenes: Preparation of Calix [4] arenes Substituted at the Lower and Upper Rims with O-Glycosyl Groups. Angew. Chem. Int. Ed. Engl. 1995, 33, 2479-2481. [CrossRef]

23. Shi, Y.; Zhang, Z. Host-guest interactions in aqueous media with p-tert.-butylcalix [4] arene bearing polyoxyethylene chains. J. Incl. Phenomen. Mol. Recognit. Chem. 1994, 18, 137-147. [CrossRef]

24. Bayrakci, M.; Ertul, Ş.; Yilmaz, M. Synthesis of new water-soluble phosphonate calixazacrowns and their use as drug solubilizing agents. J. Incl. Phenom. Macrocycl. Chem. Macrocycl. Chem. 2012, 74, 293-303. [CrossRef]

25. Quaglio, D.; Mangiardi, L.; Venditti, G.; Del Plato, C.; Polli, F.; Ghirga, F.; Favero, G.; Pierini, M.; Botta, B.; Mazzei, F. Cover Feature: Site-Directed Antibody Immobilization by Resorc[4]arene-Based Immunosensors. Chem. Eur. J. 2020, 26, 8317. [CrossRef]

26. Quaglio, D.; Zappia, G.; De Paolis, E.; Balducci, S.; Botta, B.; Ghirga, F. Olefin metathesis reaction as a locking tool for macrocycle and mechanomolecule construction. Org. Chem. Front. 2018, 5, 3022-3055. [CrossRef]

27. Corradi, S.; Mazzoccanti, G.; Ghirga, F.; Quaglio, D.; Nevola, L.; Massera, C.; Ugozzoli, F.; Giannini, G.; Ciogli, A.; D’Acquarica, I. Synthesis of bromoundecyl resorc[4] arenes and applications of the cone stereoisomer as selector for liquid chromatography. J. Org. Chem. 2018, 83, 7683-7693. [CrossRef] 
28. Aiello, F.; Balzano, F.; Ghirga, F.; D'Acquarica, I.; Botta, B.; Uccello-Barretta, G.; Quaglio, D. First Detection of a RutheniumCarbene-Resorc[4]arene Complex During the Progress of a Metathesis Reaction. Eur. J. Org. Chem. 2017, $2017,2407-2415$. [CrossRef]

29. Ghirga, F.; Quaglio, D.; Iovine, V.; Botta, B.; Pierini, M.; Mannina, L.; Sobolev, A.P.; Ugozzoli, F.; D'Acquarica, I. Synthesis of a double-spanned resorc[4] arene via ring-closing metathesis and calculation of aggregation propensity. J. Org. Chem. 2014, 79, 11051-11060. [CrossRef]

30. Ghirga, F.; D'Acquarica, I.; Delle Monache, G.; Toscano, S.; Mannina, L.; Sobolev, A.P.; Ugozzoli, F.; Crocco, D.; Antiochia, R.; Botta, B. Undecenyl resorc[4]arene in the chair conformation as preorganized synthon for olefin metathesis. RSC Adv. 2013, 3, 17567-17576. [CrossRef]

31. Ghirga, F.; D’Acquarica, I.; Delle Monache, G.; Mannina, L.; Molinaro, C.; Nevola, L.; Sobolev, A.P.; Pierini, M.; Botta, B. Reaction of Nitrosonium Cation with Resorc[4]arenes Activated by Supramolecular Control: Covalent Bond Formation. J. Org. Chem. 2013, 78, 6935-6946. [CrossRef]

32. Patel, M.B.; Valand, N.N.; Modi, N.R.; Joshi, K.V.; Harikrishnan, U.; Kumar, S.P.; Jasrai, Y.T.; Menon, S.K. Effect of psulfonatocalix[4]resorcinarene (PSC [4] R) on the solubility and bioavailability of a poorly water soluble drug lamotrigine (LMN) and computational investigation. RSC Adv. 2013, 3, 15971-15981. [CrossRef]

33. Acharya, A.; Samanta, K.; Rao, C.P. Conjugates of calixarenes emerging as molecular entities of nanoscience. Coord. Chem. Rev. 2012, 256, 2096-2125. [CrossRef]

34. Morozova, J.E.; Syakaev, V.; Kazakova, E.K.; Shalaeva, Y.V.; Nizameev, I.; Kadirov, M.; Voloshina, A.; Zobov, V.; Konovalov, A.I. Amphiphilic calixresorcinarene associates as effective solubilizing agents for hydrophobic organic acids: Construction of nano-aggregates. Soft Matters 2016, 12, 5590-5599. [CrossRef]

35. Angelini, G.; De Maria, P.; Fontana, A.; Pierini, M. Study of the aggregation properties of a novel amphiphilic C60 fullerene derivative. Langmuir 2001, 17, 6404-6407. [CrossRef]

36. MarvinSketch v 4.1.13 from ChemAxon. Available online: https:// chemaxon.com/products/marvin/marvinsketch/ (accessed on 15 September 2021).

37. Merget, S.; Catti, L.; Piccini, G.; Tiefenbacher, K. Requirements for Terpene Cyclizations inside the Supramolecular Resorcinarene Capsule: Bound Water and Its Protonation Determine the Catalytic Activity. J. Am. Chem. Soc. 2020, 142, 4400-4410. [CrossRef] [PubMed]

38. Elidrisi, I.; Negin, S.; Bhatt, P.V.; Govender, T.; Kruger, H.G.; Gokel, G.W.; Maguire, G.E.M. Pore formation in phospholipid bilayers by amphiphilic cavitands. Org. Biomol. Chem. 2011, 9, 4498-4506. [CrossRef]

39. Li, L.; Yao, Y.; Sun, J.; Yan, C.G. Preparation and application of tubular assemblies based on amphiphilic tetramethoxyresorcinarenes. RSC Adv. 2015, 5, 102454-102461. [CrossRef]

40. Angelini, G.; Cusan, C.; De Maria, P.; Fontana, A.; Maggini, M.; Pierini, M.; Prato, M.; Schergna, S.; Villani, C. The associative properties of some amphiphilic fullerene derivatives. Eur. J. Org. Chem. 2005, 9, 1884-1891. [CrossRef]

41. Infante, P.; Malfanti, A.; Quaglio, D.; Balducci, S.; De Martin, S.; Bufalieri, F.; Mastrotto, F.; Basili, I.; Garofalo, M.; Lospinoso Severini, L.; et al. Glabrescione B delivery by self-assembling micelles efficiently inhibits tumor growth in preclinical models of Hedgehog-dependent medulloblastoma. Cancers Lett. 2021, 499, 220-231. [CrossRef]

42. D’Alessandro, G.; Quaglio, D.; Monaco, L.; Lauro, C.; Ghirga, F.; Ingallina, C.; De Martino, M.; Fucile, S.; Porzia, A.; Di Castro, F.; et al. ${ }^{1} \mathrm{H}-\mathrm{NMR}$ metabolomics reveals the Glabrescione B exacerbation of glycolytic metabolism beside the cell growth inhibitory effect in glioma. Cell. Commun. Signal. 2019, 17, 1-12. [CrossRef] [PubMed]

43. Infante, P.; Mori, M.; Alfonsi, R.; Ghirga, F.; Aiello, F.; Toscano, S.; Ingallina, C.; Siler, M.; Cucchi, D.; Po, A.; et al. Gli1/DNA interaction is a druggable target for Hedgehog-dependent tumors. EMBO J. 2015, 34, 200-217. [CrossRef] [PubMed]

44. Lospinoso Severini, L.; Quaglio, D.; Basili, I.; Ghirga, F.; Bufalieri, F.; Caimano, M.; Balducci, S.; Moretti, M.; Romeo, I.; Loricchio, E.; et al. A smo/gli multitarget hedgehog pathway inhibitor impairs tumor growth. Cancers 2019, 11, 1518. [CrossRef] [PubMed]

45. Berardozzi, S.; Bernardi, F.; Infante, P.; Ingallina, C.; Toscano, S.; De Paolis, E.; Alfonsi, R.; Caimano, M.; Botta, B.; Mori, M. Synergistic inhibition of the Hedgehog pathway by newly designed Smo and Gli antagonists bearing the isoflavone scaffold. Eur. J. Med. Chem. 2018, 156, 554-562. [CrossRef] [PubMed] 